\title{
The enzymes of glycogen and trehalose catabolism from Hysterothylacium aduncum (Nematoda: Anisakidae)
}

\author{
Krystyna Żółtowska ${ }^{1}$, Elżbieta Lopieńska ${ }^{1}$, Jerzy Rokicki $^{2}$ and Malgorzata Dmitryjuk ${ }^{1}$ \\ ${ }^{1}$ Department of Biochemistry, Faculty of Biology, University of Warmia and Mazury, ul. Żołnierska 14, 10-561 Olsztyn, Poland; \\ ${ }^{2}$ Invertebrate Zoology Division, Gdańsk University, Al. Piłsudskiego 46, 81-378 Gdynia, Poland
}

Key words: Nematoda, Hysterothylacium aduncum, enzymes, carbohydrate metabolism, glycogen, trehalose

\begin{abstract}
The activity of $\alpha$-amylase, glucoamylase, maltase, trehalase, glycogen phosphorylase and trehalose phosphorylase was measured in extracts from larval and adult Hysterothylacium aduncum (Rudolphi, 1802), parasitic nematode of marine fish. The content of glycogen and trehalose in the worm's body was also determined. Both the hydrolytic and phosphorolytic paths of sugar decomposition are present in H. aduncum. In the larvae glycogen was utilised mainly via the hydrolytic path. In the adults the activities of phosphorolytic enzymes were higher than in the larvae. In both stages the activity of trehalose phosphorylase is present. In adult nematodes it is uncommonly high. The dominating sugars in the adults were glucose and glycogen, while in the larvae it was trehalose.
\end{abstract}

The nematode Hysterothylacium aduncum (Rudolphi, 1802) (Anisakidae) is an intestinal parasite of gadoids, less frequently it is found in representatives of other fish families (Berland 1991). Its hosts in Europe are cod (Gadus morhua) and eelpout (Zoarces viviparus). It was also found in horse mackerel (Trachurus trachurus) (Adroher et al. 1996), Greenland halibut (Boje et al. 1997) and in the Black Sea in whiting and sprat (Telli and Doran 1997). Moravec et al. (1985) found $H$. aduncum in freshwater fish from Hokkaido while Yoshinaga et al. (1987) observed the full developmental cycle of the parasite after experimental infestation of Oncorhynchus mykiss (as Salmo gairdneri).

Hysterothylacium aduncum is a parasite with a very high prevalence, having the leading position among parasitic nematodes of marine teleosts (Adroher et al. 1996). In spite of that, much less attention is devoted to it than to Anisakis simplex, a parasite frequently present jointly with it and belonging to the same family. Low interest in $H$. aduncum may result from the commonly accepted opinion that this parasite does relatively little harm to fish. Berland (1991) goes as far as to question whether it is a true parasite or a mutualist. Also the belief that infestation of homoiothermic animals with $H$. aduncum is impossible, because its larvae are highly sensitive to temperature (Huang 1988, Adroher et al. 1991), resulted in narrowing the scope of studies on this species.

The morphology and life cycle of $H$. aduncum are well known (Soleim and Berland 1981, Køie 1993, Balbuena et al. 1998, Gonzalez 1998). A number of works deal with its taxonomy (Balbuena et al. 1998, Sanchez et al. 1998, Zhu et al. 1998). On the other hand, little information was found in the available literature on its biochemistry and physiology. This study aimed at identifying the activity of the key enzymes degrading carbohydrates present in $H$. aduncum and establishing the content of the major sugars in the body of the parasite. It seems that glucose and its higher polymers such as trehalose and glycogen should be important energetic compounds for this parasite, similar to other parasitic nematodes of fish, Anisakis simplex and Cystidicola farionis (Żółtowska et al. 2000, 2001).

\section{MATERIALS AND METHODS}

The nematodes were isolated from eelpout, Zoarces viviparus (Linnaeus, 1758), caught in the Gulf of Gdańsk from January to December 2000. Larval and adult specimens of $H$. aduncum were the material for the study. After cleaning from the residues of the host's tissue nematodes were flushed in $0.65 \%$ solution of $\mathrm{NaCl}$ at $5^{\circ} \mathrm{C}$. The extracts for examination were prepared by homogenising the weighted material with 5 volumes of cold $0.65 \% \mathrm{NaCl}$. The homogenate was centrifuged at $2000 \mathrm{~g}$ for $10 \mathrm{~min}$ at $4^{\circ} \mathrm{C}$.

Materials. The glucose assay kit (GOD/POD, no. 2-121) was purchased from Cormay Z.P. (Lublin, Poland). The following chemicals from Sigma were used: amyloglucosidase from Aspergillus niger (A 7420), glucose-6-phosphate dehydrogenase from bakers yeast (G 7877), phosphoglucomutase from rabbit muscle (P 3397), AMP, NADP-Na salt, glucose-1,6-bisphosphate, maltose, trehalose, glycogen from oyster, and soluble potato starch.

Sugar assays. The concentration of glycogen was determined according to Sølling and Esmann (1975), glucose using a glucose assay and trehalose by enzymatic method according to Kienle et al. (1993), using acid trehalase isolated from Saccharomyces cerevisiae suc2 mutant according to Mittenbühler and Holzer (1988).

Enzyme assays. The activity of $\alpha$-amylase was measured according to Caraway (1959) and expressed in the international units $(\mathrm{u})$. The incubation mixture $(1 \mathrm{ml})$ contained 
$1 \mathrm{mg}$ of starch in $70 \mathrm{mM}$ veronal/ $\mathrm{Na}$ acetate buffer $(\mathrm{pH} 7.6)$. The incubation lasted $30 \mathrm{~min}$ at $30^{\circ} \mathrm{C}$. The activity of $\alpha$ glucosidases: glucoamylase, maltase and trehalase were assayed according to Dahlqvist (1968), by measuring the glucose liberated. The glucoamylase activity was measured after $1 \mathrm{~h}$ incubation at $30^{\circ} \mathrm{C}$. The incubation mixture $(1 \mathrm{ml})$ contained $2 \mathrm{mg}$ of glycogen in $70 \mathrm{mM}$ veronal $/ \mathrm{Na}$ acetate buffer ( $\mathrm{pH}$ 4.6). Maltase activity was assayed using as substrate $100 \mathrm{mM}$ maltose in $70 \mathrm{mM}$ veronal/Na acetate buffer $\mathrm{pH}$ 5.4. The reaction time was $30 \mathrm{~min}$ for the larvae and 60 min for the adults. Trehalase activity was determined after $1 \mathrm{~h}$ incubation at $30^{\circ} \mathrm{C}$ with $100 \mathrm{mM}$ trehalose in $70 \mathrm{mM}$ veronal/ $\mathrm{Na}$ acetate buffer $(\mathrm{pH} 6.12)$. The activity of glycogen phosphorylase was measured towards glycogen degradation. The reaction mixture in volume of $1 \mathrm{ml}$ contained $1 \mathrm{mg}$ of glycogen in $70 \mathrm{mM}$ sodium phosphate $(\mathrm{pH} 7.1)$ and $0.01 \mathrm{mM}$ AMP. The amount of D-glucose-1-phosphate, released after 15 min incubation at $30^{\circ} \mathrm{C}$, was determined by the enzymatic method according to Michal (1984). Trehalose phosphorylase was assayed in the direction of trehalose degradation according to Wannet et al. (1998). The incubation mixture contained $100 \mathrm{mM}$ trehalose in $70 \mathrm{mM}$ Sörensen buffer $(\mathrm{pH}$ 7.1). After incubation at $30^{\circ} \mathrm{C}$ for $15 \mathrm{~min}$, in the reaction mixture the contents of D-glucose-1-phosphate was determined according to Michal (1984) and the amount of glucose was assayed. The enzymatic activity was expressed in units (u) corresponding to release of $1 \mu$ mole of the product in 1 hour. They were converted to $1 \mathrm{mg}$ protein.

The protein content was determined according to Bradford (1976). The results represent the mean of three repetitions of the tests.

\section{RESULTS}

The content of glycogen and glucose was 3 and 10 times higher in $H$. aduncum adults than in the larvae (Table 1). Different results were obtained for trehalose, where concentration was ca. 2.5 times higher in the larvae than in the adults. In contrast, the activities of trehalose catabolism enzymes were lower in the larvae than in the adult nematodes (Table 2). It was impossible to assay the activity of trehalose phosphorylase basing on the amount of glucose, because trehalase in crude extracts from $H$. aduncum was still active at $\mathrm{pH} 7.1$. The ratio of glucose to glucose-1-phosphate was always higher than 1 , ranged from 1.3 to 1.6 . We decided to determine trehalose phosphorylase activity spectrophotometrically by enzymatic measurement of the glucose-1-phosphate liberated from trehalose. In the adults the measured activity of trehalose phosphorylases was very high, being 5 times higher than in the larvae, while the activity of trehalase was only 2 times higher. Also glycogen phosphorylase was more active in the adult nematodes than in the larvae.

Amylolytic enzymes showed similar activity in both developmental stages. For $\alpha$-amylase the mean activity was $0.55 \mathrm{u} / \mathrm{mg}$ and $0.57 \mathrm{u} / \mathrm{mg}$, and for glucoamylase $5.11 \mathrm{u} / \mathrm{mg}$ and $6.12 \mathrm{u} / \mathrm{mg}$, respectively, for the larvae and adults. The activity of maltase was 5 times higher in the larvae than in the adult nematodes (Table 2).

Table 1. The concentration of sugars in the body of Hysterothylacium aduncum.

\begin{tabular}{|l|c|c|}
\hline \multirow{2}{*}{ Carbohydrate } & \multicolumn{2}{|c|}{ Content $(\mathrm{mg} / \mathrm{g}$ fresh tissue $)$} \\
& Larvae & Adults \\
\hline \multirow{2}{*}{ Glycogen } & $2.91^{\mathrm{a}}$ & 9.63 \\
& $(1.78-4.06)^{\mathrm{b}}$ & $(6.95-13.05)$ \\
Trehalose & 8.24 & 3.48 \\
& $(7.87-8.45)$ & $(2.74-4.82)$ \\
Glucose & 2.85 & 30.91 \\
& $(1.98-3.34)$ & $(25.99-38.77)$ \\
\hline
\end{tabular}

$a-$ mean of three experiments, $b$ - range

Table 2. The enzymes of carbohydrate metabolism from Hysterothylacium aduncum.

\begin{tabular}{|l|c|c|}
\hline \multirow{2}{*}{ Enzyme } & \multicolumn{2}{|c|}{ Activity (u/mg) } \\
\cline { 2 - 3 } & Larvae & Adults \\
\hline \multirow{2}{*}{ Alpha-amylase } & $0.55^{\mathrm{a}}$ & 0.57 \\
& $(0.33-0.79)^{\mathrm{b}}$ & $(0.38-0.79)$ \\
\hline Glucoamylase & 5.11 & 6.12 \\
& $(3.32-7.04)$ & $(4.60-8.89)$ \\
\hline \multirow{2}{*}{ Maltase } & 26.70 & 5.79 \\
& $(18.8-33.3)$ & $(4.56-8.06)$ \\
\hline \multirow{2}{*}{ Trehalase } & 4.97 & 10.29 \\
& $(3.65-6.99)$ & $(8.05-14.76)$ \\
\hline \multirow{2}{*}{ Trehalose phosphorylase } & 0.222 & 1.194 \\
& $(0.156-0.283)$ & $(0.960-1.563)$ \\
\hline \multirow{2}{*}{ Glycogen phosphorylase $^{\mathrm{c}}$} & 0.145 & 0.252 \\
& $(0.080-0.235)$ & $(0.154-0.315)$ \\
\hline
\end{tabular}

$\mathrm{a}-$ mean of three experiments, $\mathrm{b}$ - range, $\mathrm{c}-$ activity measured in the catabolic direction

\section{DISCUSSION}

The activity of enzymes of sugar metabolism results from different living conditions of parasites (Von Brand 1973). We observed that the larvae of intestinal parasites of fish, Hysterothylacium aduncum and Anisakis simplex, possessed a similar level of glycogen phosphorylase (Źółtowska et al. 2000). It was by one order lower than that measured for the larvae of the tissue nematode Cystidicola farionis. The high activity of glycogen phosphorylase in $C$. farionis larvae was in positive correlation with a higher level of glycogen in its body (Żółtowska et al. 2001) and, as we suppose, larger in the immediate environment of that parasite than that generally encountered by intestinal nematodes. The comparison of $\alpha$-amylase activities also confirmed Von Brand's suggestion. The activity of that enzyme, which is important in degrading mainly food polysaccharides, in the intestinal parasite $H$. aduncum $(0.55$ $\mathrm{u} / \mathrm{mg}$ ) was higher by one order than that in the tissue parasite $C$. farionis $(0.010 \mathrm{u} / \mathrm{mg})$ (Żółtowska et al. 2001). 
As established in our studies, both paths of sugar decomposition were present in $H$. aduncum: the hydrolytic path represented by amylases and disaccharidases and the phosphorolytic path represented by glycogen phosphorylase and trehalose phosphorylase (Table 2). In the adult nematodes the activity of both phosphorylases glycogen and trehalose - was significantly higher than in the larvae. We have never found in nematodes such high activity of trehalose phosphorylase as was measured in the adult $H$. aduncum (Dmitryjuk et al. 2000, Żołtowska et al. 2000, 2001). We suppose that the phosphorolytic pathways of sugar catabolism become much more important during the worm's development.

The activity of the major enzymes initiating the hydrolytic decomposition of glycogen, $\alpha$-amylase and glucoamylase was similar for both developmental stages (Table 2). A difference, however, was observed in the activity of disaccharidase. The activity of maltase, involved in further decomposition of the products of amylolysis, was almost 5 times higher in the larvae than in the adults. This is supposed to lead to efficient utilisation of glycogen in the larvae mainly along the hydrolysis path as the level of glycogen in them was three times lower than in the adult $H$. aduncum (Table $1)$.

The larvae and adults of $H$. aduncum differ in the content of reserve sugars that they possess. In the adult nematodes glucose was the dominating sugar. Also the concentration of glycogen was significantly higher in the adults than in the larvae. On the other hand, trehalose was the main sugar in the larvae (Table 1). It seems that the differences in the contents of individual saccharides may result partly from the activities of enzymes decomposing them in the larvae and in the adults. The high activity of trehalase and trehalose phosphorylase measured in the adult nematodes may be the cause of the low level of that disaccharide in them. Similar results were obtained for $C$. farionis. In that fish parasite the activity of trehalose catabolism enzymes was also higher in the adults than in the larvae (Żółtowska et al. 2001). The negative correlation between the level of trehalose and the activity of trehalase was described by Behm (1997) in many other parasitic nematodes.

The issue whether or not $H$. aduncum can be dangerous for mammals and humans remains open. Studies by Gonzalez (1998) excluded the possibility of infesting mice with $\mathrm{L}_{3}$ and $\mathrm{L}_{4}$ larvae of $H$. aduncum. On the other hand, a well-documented case of anisakiosis in a man was described in Japan (Yagi et al. 1996). The potential possibility of including humans as accidental hosts in the life cycle of $H$. aduncum is indicated by the described cases of appearance of this nematode in sea birds feeding on fish (Olafsdottir et al. 1996) and porpoises living in the coastal waters of Denmark (Herreras et al. 1997). Such reports indicate the need for more detailed studies on the biochemistry and physiology of this parasite.

Acknowledgements. The authors would like to thank Dr. Harald Zähringer from the Institute of Biochemistry and Molecular Biology, University of Freiburg for valuable advice and Dr. Stefan Hohmann from the Institute for Cell and Molecular Biology/Microbiology, Göteborg University for donating a mutant Saccharomyces cerevisiae strain suc2 from which acid trehalase was isolated. This study was supported by KBN (State Committee for Scientific Research), grant No. 6BO4B02616.

\section{REFERENCES}

ADROHER F.J., VALERO A., RUIZ-VALERO J., IGLESIAS L. 1996: Larval anisakids (Nematoda: Ascaridoidea) in horse mackerel (Trachurus trachurus) from fish market in Grenada (Spain). Parasitol. Res. 82: 253-256.

ADROHER F.J., VALERO A., WOLFF M., RUIZ-VALERO J. 1991: Mantenimiento y ecdisis in vitro de Hysterothylacium aduncum. International Congreso de las Asociaciones Sudoccidental Europeas de Parasitologia I, Valencia, Spain, 1-5 July, Compendio de Resumenes de las Comunicaciones, p. 124

BALBUENA J.A., KARLSBAKK E., SAKSVIK M., KVENSETH A.M., NYLUND A. 1998: New data on the early development of Hysterothylacium aduncum (Nematoda, Anisakidae). J. Parasitol. 84: 615-617.

BEHM C.A. 1997: The role of trehalose in physiology of nematodes. Int. J. Parasitol. 27: 215-229.

BERLAND B. 1991: Hysterothylacium aduncum (Nematode) chez les poissons. ICES identification leaflets for diseases and parasites of fish and shellfish, No. 44. International
Council for Exploration of the Sea, Copenhagen, Denmark, pp. 2-4.

BOJE J., RIGET F., KØIE M. 1997: Helminth parasites as biological tags in population studies of Greenland halibut (Reinhardtius hippoglossoides (Walbaum), in the northwest Atlantic. ICES J. Mar. Sci. 54: 886-895.

BRADFORD J. 1976: A rapid sensitive method for quantitation of microgram quantities of protein utilising the principle of protein-dye binding. Anal. Biochem. 72: 248-254.

CARAWAY W.T. 1959: A stable starch substrate for determination of amylase in serum and other body fluids. Am. J. Clin. Pathol. 32: 97-99.

DAHLQVIST A. 1968: Assay of intestinal disaccharidases. Anal. Biochem. 22: 99-107.

DMITRYJUK M., ŻÓŁTOWSKA K., ŁOPIEŃSKA E. 2000: Aktywność trehalazy i fosforylazy trehalozy w tkankach Ascaris suum Goeze, 1782 (Nematoda). Streszczenia, XXXVI Zjazd Polskiego Towarzystwa Biochemicznego, Poznań, 2000, P05-69, p. 126. 
GONZALEZ L. 1998: Experimental infection of mice with Hysterothylacium aduncum (Nematoda: Anisakidae) larvae from marine-farmed trout in Chile. Arch. Med. Vet. 30: 139142.

HERRERAS M.V., KAARSTAD S.E., BALBUENA J.A., KINZE C.C., RAGA J.A. 1997: Helminth parasites of the digestive tract of the harbour porpoise Phocoena phocoena in Danish waters: a comparative geographical analysis. Dis. Aquat. Org. 28: 163-167.

HUANG W. 1988: Anisakidés et anisakidoses humaines. Deuxième partie: enquête sur les Anisakidés de poissons commerciaux du marché parisien. Ann. Parasitol. Hum. Comp. 63: 197-208.

KIENLE I., BURGERT M., HOLZER. H. 1993: Assay of trehalose with acid trehalase purified from Saccharomyces cerevisiae. Yeast 9: 607-611.

KØIE M. 1993: Aspects of life cycle and morphology of Hysterothylacium aduncum (Rudolphi, 1802) (Nematoda, Ascaridoidea, Anisakidae). Can. J. Zool. 71: 1289-1296.

MICHAL G. 1984. D-Glucose-1-phosphate. In: H.U. Bergmeyer (Ed.), Methods of Enzymatic Analysis, Vol. 6. Third Edition. Verlag Chemie, Weinheim, pp. 185-191.

MITTENBÜHLER K., HOLZER H. 1988: Purification and characterization of acid trehalase from the yeast suc2 mutant. J. Biol. Chem. 263: 8537-8543.

MORAVEC F., NAGASAWA K., URAWA S. 1985: Some fish nematodes from fresh waters in Hokkaido, Japan. Folia Parasitol. 32: 305-316.

OLAFSDOTTIR D., LILLIENDAHL K., SOLMUNDSSON J., SKIRNISSON K., SKORPING A. 1996: Nematode infections in Icelandic seabirds. Proc. Scand. Soc. Parasitol., Special Symposium, Parasites and Ecology of Marine and Coastal Birds, Stykkisholmur, Iceland 15-18 June 1996. Bull. Scand. Soc. Parasitol. 2: 124-125.

SANCHEZ J.M., PANIAGUA I., VALERO A. 1998: Contribution to the knowledge of Hysterothylacium aduncum through electrophoresis of the enzymes glucose phosphate isomerase and phosphoglucomutase. Parasitol. Res. 84: 160-163.
SOLEIM O., BERLAND B. 1981: The morphology of Thynnascaris adunca (Rudolphi) (Nematoda, Ascaridoidea). Zool. Scr. 10: 167-182.

SØLLING H., ESMANN W. 1975: A sensitive method of glycogen determination in the presence of interfering substances utilizing the filter-paper technique. Anal. Biochem. 68: 664-668.

TELLI F., DORAN F. 1997: Pathologic abnormalities of fish in Turkish coastal waters of the eastern Black Sea. Turkish J. Zool. 21: 85-90.

von BRAND T. 1973: Biochemistry of Parasites. Second Edition. Academic Press, New York-London, pp. 52-55, 93-96.

WANNET W.J.B., den CAMP H.J.M.O., WISSELINK H.W., van der DRIFT C., Van GRIENSVEN L.J.L.D., VOGELS G.D. 1998: Purification and characterization of trehalose phosphorylase from the commercial mushroom Agaricus bisporus. Biochim. Biophys. Acta 1425: 177-188.

YAGI K., NAGASAWA K., ISHIKURA H., NAKAGAWA A., SATO N., KIKUCHI K., ISHIKURA H. 1996: Female worm Hysterothylacium aduncum excreted from human: a case report. Jpn. J. Parasitol. 45: 12-23.

YOSHINAGA T., OGAWA K., WAKABAYASHI H. 1987: Experimental life cycle of Hysterothylacium aduncum (Nematoda, Anisakidae) in fresh water. Fish Pathol. 22: 243-251.

ZHU X-Q., GASSER R.B., PODOLSKA M., CHILTON N.B., ZHU X-Q. 1998: Characterisation of anisakid nematodes with zoonotic potential by nuclear ribosomal DNA sequences. Int. J. Parasitol. 28: 1911-1921.

ŻÓŁTOWSKA K., ŁOPIEŃSKA E., ROKICKI J. 2000: Content of carbohydrates and activity of sugar metabolism enzymes present in stage III larvae of Anisakis simplex. Acta Parasitol. 45: 186.

ŻÓŁTOWSKA K., ŁOPIEŃSKA E., ROKICKI J., DMITRYJUK M. 2001: The enzymes of carbohydrate metabolism from Cystidicola farionis (Cystidicolidae). Wiad. Parazytol. 47: 311-316. (In Polish, with English abstract.)

Accepted 6 February 2002 